\title{
ANALISIS KANDUNGAN MERKURI (Hg) PADA AIR DAN DAGING IKAN PATIN SIAM (Pangasius hypopthalmus) Di KJA DANAU SIPIN JAMBI
}

\author{
Syahrizal $^{1 *}$ dan M. Yusuf Arifin ${ }^{1}$ \\ Program Studi Budidaya Perairan, Fakultas Pertanian Universitas Batanghari \\ J1. Slamet Riyadi, Broni Jambi. 36122. Telp. +62074160103 \\ 1*Email korespondensi : syahrizal.syukur@yahoo.com
}

\begin{abstract}
Environment Agency Jambi Province in 2014 stipulates that the Batanghari River uncategorised heavy pollution with the effluent of $0.3265 \mathrm{ppm}$. The river water flow into the Lake Sipin, so worried farmers catfish (Pangasius hypopthalmus) in the floating nets cage on heavy metal pollution $\mathrm{Hg}$ when exceeding quality standards. The content of $\mathrm{Hg}$ was observed through the method of survey study purposive sampling with 4 stations for 3 weeks of observation with sample analysis Atomic Absorption Spectrophotometer. The observation that the accumulation of heavy metals mercury $(\mathrm{Hg})$ meat catfish in the lake Sipin from 0.0930 to $0.3960 \mathrm{ppm} . \mathrm{Hg}$ content is in torelansi SNI standards for heavy metals Hg categories food fishery products including mollusks and shrimp is 1 ppm and 0.5 ppm for predatory fish. So fish farming Lake Sipin still safe for consumption humans..Hg value of water is observed from 0.0001 to $0.0009 \mathrm{ppm}$. Hg content was lower when compared to the water quality standard by the Ministry of Environment No. 51 In 2004 the threshold value for the biota is $0.001 \mathrm{mg} / \mathrm{l}$ (ppm). Then the category of heavy metal content of $\mathrm{Hg}$ in the waters of Lake Sipin still at the threshold of normal. Occurrence repaired Hg waters presumably because the number found fish brooms, Hypostomus plecostomus and plant water hyacinth, Eichhornia crassipes which absorbed $\mathrm{Hg}$ in the waters. The state of water quality when the observation temperatures averaging $30-32{ }^{\circ} \mathrm{C}, \mathrm{pH} 6.6$ to 7.4 and $\mathrm{DO} 7.0$ to $8.4 \mathrm{ppm}$. The range of this parameter is feasible for the cultivation of catfish (Pangasius Hyphopthalmus), as it supports the growth and survival.
\end{abstract}

Keywords: Bioaccumulation Hg, Lake Sipin, catfish

\begin{abstract}
Abstrak
Badan Lingkungan Hidup Provinsi Jambi pada tahun 2014 menetapkan bahwa Sungai Batanghari dikategorikan tercemari berat dengan limbah 0,3265 ppm. Air sungai ini mengalir ke Danau Sipin, sehingga para petani ikan patin (Pangasius hypopthalmus) di KJA kawatir terjadi pencemaran logam berat $\mathrm{Hg}$ melebihi standar. Kandungan $\mathrm{Hg}$ diamati melalui metode studi survei purposive sampling dengan 4 stasiun selama 3 minggu pengamatan sampel dengan analisis Spektrofotometer Serapan Atom. Hasil pengamatan terhadap akumulasi logam merkuri (Hg) pada ikan patin di Danau Sipin dari 0,0930 sampai 0,3960 ppm. Katagori kandungan $\mathrm{Hg}$ yang bisa di torelansi menurut standar SNI untuk produksi pangan perikanan termasuk moluska dan udang adalah $1 \mathrm{ppm}$ dan 0,5 ppm untuk ikan predator. Jadi budidaya ikan Danau Sipin masih aman untuk dikonsumsi manusia. Nilai $\mathrm{Hg}$ airnya dari 0,0001 sampai 0,0009 ppm. Kandungan $\mathrm{Hg}$ ini lebih rendah bila dibandingkan dengan standar kualitas air oleh Kementerian Lingkungan Hidup No. 51 Pada tahun 2004 nilai ambang untuk biota adalah 0,001 mg / 1 (ppm). Kemudian kategori kandungan logam berat $\mathrm{Hg}$ di perairan Danau Sipin masih di ambang normal. Terjadinya perbaikan $\mathrm{Hg}$ air diduga karena ditemukan sejumlah ikan sapu-sapu, Hypostomus plecostomus dan tanaman eceng gondok, Eichhornia crassipes yang dapat menyerap $\mathrm{Hg}$ di perairan. Keadaan kualitas air pengamatan berupa suhu rata-rata $30-32{ }^{\circ} \mathrm{C}$, pH 6,6 sampai 7,4 dan DO 7,0 sampai 8,4 ppm. Kisaran parameter ini layak untuk budidaya ikan patin (Pangasius Hyphopthalmus), karena mendukung untuk pertumbuhan dan kelangsungan hidup.

Kata kunci: Bioakumulasi Hg, Danau Sipin, ikan patin
\end{abstract}

Diterbitkan oleh Program Studi Budidaya Perairan Fakultas Pertanian Unbari

Halaman 9 


\section{PENDAHULUAN}

Kebutuhan manusia pada ikan sebagai sumber pagan yang baik sudah berlangsung sejak lama disebabkan nenek moyang kita hidup dipinggiran perairan, baik dipingggir sungai maupun dipesisir. Hal lain sungai dan laut sebagai sarana transportasi, diikuti kebutuhan MCK (mandi, cuci dan kakus). Pada waktu itu berburu ikan sebagai suber makanan lebih mudah didapat dan saat ini fungsi tersebut menurun tajam. Penurunan produksi perairan, ikan dan biota lainnya terancam oleh kebtuhan manusia juga, dianataranya disebabkan pembangunan industri dan pertanian.

Meningkatnya kegiatan pertambangan, industri dan pertanian sepanjang daerah aliran sungai (DAS) mempercepat peningkatan konsentrasi merkuri $(\mathrm{Hg})$ terlarut dalam badan perairan. Badan Lingkungan Hidup Provinsi Jambi tahun 2014 menetapkan bahwa peningkatan konsentrasi $\mathrm{Hg}$ di perairan Sungai Batanghari sudah mengalami pencemaran dengan kategori golongan kelas D dengan effluen sebesar 0,3265 ppm (Kompas, 2014). Konsentrasi $\mathrm{Hg}$ tersebut merupakan konsentrasi yang tinggi, kemungkinan sudah toksik buat ikan dan tidak aman untuk pangan. Menurut Carvalho dan Fernandes (2006) bahwa merkuri dapat terbioakumulasi dan menjadi racun bagi organisme budidaya. Kelebihan $\mathrm{Hg}$ tersebut menyebabkan gangguan pada sejumlah proses fisiologis yang meliputi terganggunya regulasi pertukaran ion di insang sehingga menurunkan penyerapan oksigen yang residunya terikat pada protein dan enzim.

Ikan patin (Pangasius hypopthalmus) merupakan salah satu komoditas perikanan dalam program percepatan industrialisasi dari jenis komoditas perikanan budidaya di Propinsi Jambi dengan jumlah produksi pada tahun 2012 sebesar 651.000 ton (KKP 2014). Komoditas ikan ini dibudidayakan khususnya oleh masyarakat Jambi di sepanjang perairan Jambi, termasuk di Danau Sipin. Menurut BLH Provinsi Jambi, kandungan Hg pada perairan Sungai Batanghari berkisar antara 0,053-0,68 ppm. Nilai ini lebih tinggi dari kandungan maksimum $\mathrm{Hg}$ pada Keputusan Menteri Negara Lingkungan Hidup Nomor : 115 Tahun 2003 tentang baku mutu air golongan $\mathrm{C}$ yang besarnya 0,002 mg/L (Makarim, 2003). Oleh karena itu, studi mengenai toksisitas dan bioakumulasi Hg terhadap ikan patin di KJA Danau Sipin yang sumber airnya berasal dari Sungai Batanghari perlu dilakukan sebagai tindakan antisipasi pencegahan atau penanggulangan pencemaran $\mathrm{Hg}$.

\section{METODOLOGI PENELITIAN}

Penelitian ini dilaksanakan selama 3 bulan (April-Juli 2016) dengan tempat pelaksananan di Perairan Danau Sipin Jambi. Metode yang digunakan adalah metode survey yakni melihat konsentrasi $\mathrm{Hg}$ air dan $\mathrm{Hg}$ pada daging ikan di KJA perairan Danau Sipin Jambi untuk 4 stasiun pengambilan sampel yang berbeda, yakni 2 stasiun pada air mengalir dan 2 sampel pada air tenang. Titik stasiun pengambilan sampel bersifat non probability dan purposive sampling yakni pengambilan sampel tanpa peluang dan karena pertimbangan tertentu yang dipilih secara sengaja.

Pengambilan sampel $\mathrm{Hg}$ air dan $\mathrm{Hg}$ daging ikan dilakukan setiap 7 hari selama periode 3 minggu priode pengamatan penelitian dan diikuti pengamatan analisa kualitas air. Sampel $\mathrm{Hg}$ air diambil dengan menggunakan botol sampel berukuran $250 \mathrm{ml}$ yang sudah ditetesi larutan asam nitrat sebanyak tiga tetes sesuai teknis prevarasi sampel, sampel air di label sesuai dengan tiitk pengambilan dan disimpan di dalam cool box untuk siap di analisis. Pengambilan sampel $\mathrm{Hg}$ daging ikan dilakukan dengan cara menangkap ikan pada lokasi stasiun yang ditentukan, jenis ikan sudah ditentukan yakni ikan patin berukuran $40-60 \mathrm{~cm}( \pm 1,2 \mathrm{Kg})$. Ikan tersebut dibedah dengan alat bedah dan 
diambil bagian daging pada punggung atas ikan. Daging tersebut disimpan di dalam botol sampel yang sudah disediakan. Prosedur ini di lakukan selama periode pengambilan sampel dan berlaku untuk semua titik atau stasiun pengambilan.

Kandungan $\mathrm{Hg}$ pada air dan daging diuji dengan analisis Atomic Absorption Spectrophotometer (AAS) dan diamati pula Faktor Konsentrasi (FK) yakni merupakan perbandingan rasio kadar logam dalam tubuh ikan dengan kadar logam dalam air yang dinilai denga kategori tingkat akumulasi berdasarkan (Van Esch, 1977) yaitu : FK < 100 (rendah), $100<\mathrm{FK} \leq 1000$ dan FK $>1000$ (tinggi) Data yang diperoleh disajikan dalam bentuk tabel dan gambar grafik dan kemudian analisis secara deskriptif

\section{HASIL DAN PEMBAHASAN Kandungan Hg Ikan}

Hasil analisis kandungan logam berat $(\mathrm{Hg})$ yang terakumulasi di dalam daging ikan patin (Pangasiu hyphopthalmus) yang diperoleh dari 4 (empat) stasiun pengamatan dan 3 (tiga) minggu pengambilan pada lokasi air tenang (lentik) 2 (dua) stasiun dan air mengalir (lotik) 2 (dua) stasiun di KJA perairan Danau Sipin Kota Jambi. Hasil pengamatan dapat dilihat pada Tabel 1 berikut ini

Tabel 1. Kandungan logam berat Merkuri $(\mathrm{Hg})$ di dalam daging ikan patin (Pangasius hyphopthalmus) di KJA Danau Sipin Jambi (ppm)

\begin{tabular}{|l|l|c|c|c|c|c|}
\hline \multirow{2}{*}{ No } & Stasiun & \multicolumn{2}{|c|}{ Waktu Pengambilan Data } & \multirow{2}{\text{Rataan}}{} & $\begin{array}{c}\text { Kedalaman } \\
(\mathrm{m})\end{array}$ \\
\cline { 3 - 5 } & & Minggu 1 & Minggu 2 & Minggu 3 & & \\
\hline & I. Lentik & & & & & 4,0 \\
\hline 1 & St11 & 0,2970 & 0,1940 & 0,2480 & 0,2460 & 5,0 \\
\hline & St12 & 0,3170 & 0,2110 & 0,3960 & 0,3080 & 9,0 \\
\hline & Jumlah & 0,6140 & 0,4050 & 0,6440 & 0,5543 & 4,5 \\
\hline & Rataan & 0,3070 & 0,2020 & 0,3220 & 0,2772 & \\
\hline & 1. Lotik & & & & & 3,5 \\
\hline 3 & St23 & 0,1810 & 0,2990 & 0,1060 & 0,1950 & 3,7 \\
\hline 4 & St24 & 0,1460 & 0,1080 & 0,0930 & 0,1370 & 7,1 \\
\hline & Jumlah & 0,3920 & 0,4070 & 0,1990 & 0,3320 & 3,6 \\
\hline & Rataan & 0,1960 & 0,2035 & 0,0995 & 0,1660 & \\
\hline
\end{tabular}

Dari tabel 1 di atas dapat dilihat bahwa kandungan logaam berat $\mathrm{Hg}$ pada daging ikan patin dari seluruh pengamatan selama penelitian berada pada kisaran 0,0930 0,3960 ppm dan rataan 0,1660 - 0,2772 ppm. Logam berat $\mathrm{Hg}$ pada daging ikan tersebut diduga diperoleh dari sumber air Sungai Banghari. Menurut Suhandi dan Sabanto (2005) menyatakan bahwa kontaminasi logam berat merkuri (Hg) dalam sungai dapat terjadi akibat proses alamiah (pelapukan batuan terminerilisasi), proses pengolahan emas secara tradisional (amalgamasi), maupun proses industri yang menggunakan bahan baku yang mengandung logam berat merkuri $(\mathrm{Hg})$. Menurut Riani (2012) bahwa bahan beracun dan berbahaya seperti logam berat, terdapat di dalam ekosistem perairan tawar dan laut bukan hanya berasal dari kegiatan industri, tapi juga berasal dari kegiatan lain seperti dari limbah domestik, limbah pertanian, limbah rumah sakit, limbah dari berbagai kegiatan ekonomi lain yang ada di darat dan sebagainya. limbah dari pembakaran BBM seperti logam berat, lepasnya emisi NOx, $\mathrm{SOx}$, dan $\mathrm{CO}_{2}$. Logam merkuri banyak digunakan dalam berbagai kegiatan manusia, 
antara lain pabrik, alat-alat listrik, pabrik klor alkali, pertanian, cat, peralatan kedokteran gigi, penggunaan di laboratorium, katalis dan farmasi (Darmono 1995).

Hasil kisaran pengamatan $\mathrm{Hg}$ rataan 0,1660 - 0,2772 ppm pada daging ikan dapat dikatagorikan sebagai kandungan dibolehkan untuk dikosumsi menurut Standar Nasional Indonesia (SNI). Menurut SNI 7387: 2009 bahwa batas pencemaran logam berat $\mathrm{Hg}$ katagori pagan produk dari perikanan termasuk moluska dan udang adalah 1 $\mathrm{mg} / \mathrm{Kg}(\mathrm{ppm})$ dan untuk ikan predator $0,5 \mathrm{mg} / \mathrm{Kg}$ bahan. Jadi kadar logam berat $\mathrm{Hg}$ berada pada ikan sampel dikisaraan rataan 0,1660 - 0,2772 ppm dapat dikatagorikan sudah temasuk pada ambang mengkwatirkan untuk ikan kosumsi gagi keamanan pangan. Menurut Raja et al. (2009). bahwa logam berat dapat masuk ke dalam tubuh manusia melalui makanan, menyebabkan bahaya kesehatan yang serius. Efek $\mathrm{Hg}$ terhadap kesehatan manusia, seperti dapat menghambat jalan darah ke otak, merusak fungsi ginjal dan hati, mengganggu proses metabolisme dari sistem syaraf, dan jika bersifat akut maka dapat menyebabkan disfungsional pada organ lainnya (Sudarmaji 2006).

Merkuri merupakan logam berat yang mempunyai daya racun paling tinggi dibandingkan dengan logam berat lainnya serta mempunyai kemampuan untuk terakumulasi pada makhluk hidup (CCME dalam Riani, 2012). Logam berat $\mathrm{Hg}$ berbahaya karena bersifat biomagnifikasi sehingga dapat terakumulasi dalam jaringan tubuh organisme melalui rantai makanan. Organisme yang berada pada rantai yang paling tinggi (top carnivora) memiliki kadar merkuri yang lebih tinggi dibanding organisme dibawahnya (Hutagalung dalam Apriadi 2005).

Untuk kadar Hg pada daging ikan pada ekologi air tidak mengalir (lentik) jumlah rataan $0,2772 \mathrm{ppm}$ dan pada ekologi air mengalir (lotik) jumlah rataan 0,1663 ppm. Okumulasi $\mathrm{Hg}$ tersebut dapat dilihat pada grafik gambar 4.

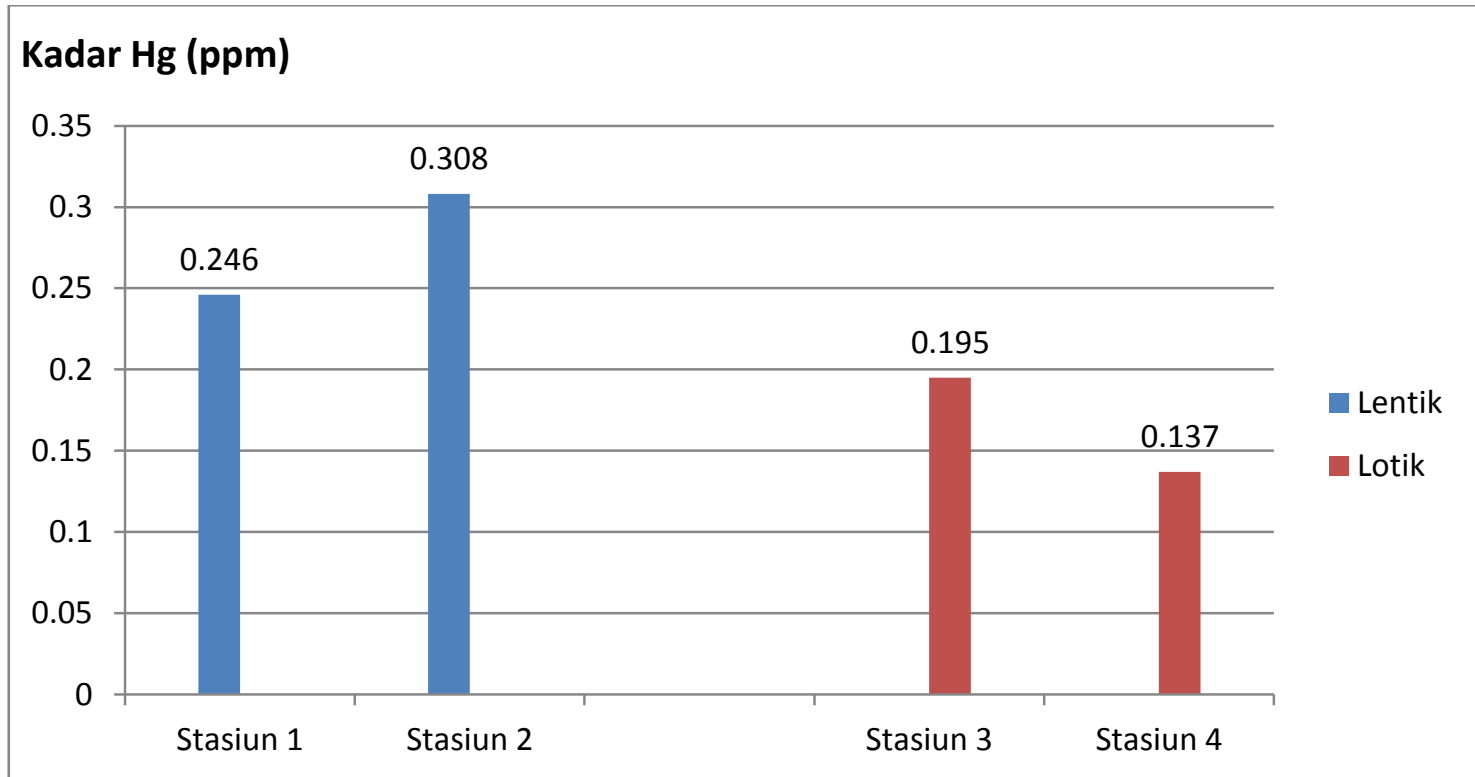

Gambar 4. Kadar Rataan Logam Berat Hg Di Dalam Sampel Daging Ikan Patin Yang Diambil Di KJA Danau Sipin Jambi

Tinggi dan rendahnya kandungan merkuri pada daging ikan sampel, diduga dipengaruhi oleh posisi stasiun pengambilan sampel. Stasiun yang air yang lebih dalam kondisi arus air lebih tenang dibandingkan air yang lebih dangakal. Stasiun 1 dan 2 
punya ekologi air mengalir ( $\pm 6 \mathrm{~m} /$ menit), sedangakan pada stasiun 3 dan 4 ekologi air tenang $( \pm 0,6 \mathrm{~m} /$ menit $)$ dipermukaan air. Nilai logam $\mathrm{Hg}$ pada ikan sampel yang tertinggi, hal ini diduga disebabkan oleh terbawa kandungan merkuri yang terdapat dari Sungai Batanghari yang telah mengalami pengendapan pada temapat yang lebih dalam di Danau Sipin. Pada tempat yang dalam terjadi penumpukan unsur Hg. Logam ini masuk kedalam tubuh ikan patin melalui proses resfirasi dan makan. Menurut Lasut (2009) bahwa organisme perairan dapat mengakumulasi merkuri dari air, sedimen, dan makanan yang dikonsumsi. Jalur masuknya $\mathrm{Hg}$ ke dalam tubuh ikan diawali ketika ion merkuri anorganik diubah menjadi merkuri organik oleh bakteri, yaitu dalam bentuk metil merkuri dan etil merkuri yang terlarut. Oleh bakteri yang aerob, ion merkuri akan di endapkan dalam bentuk metil merkuri dan kemudian diuraikan menjadi ion metil merkuri dan uap merkuri. Ion metil merkuri yang terdapat di dalam air akan mudah diambil oleh plankton dan di dalam tubuh plankton, konsentrasinya akan menjadi berlipat ganda. Oleh bakteri yang aerob, ion merkuri lansung ditransfer menjadi metil atau etil merkuri dan menjadi bagian dari tubuh bakteri. Sehingga bakteri akan dimangsa oleh mikroorganisme lain yang ada di air seperti plankton, dan selanjutnya plankton akan dimangsa oleh ikan. Ada tiga bentuk merkuri yang masuk ke dalam lingkungan yaitu merkuri elemental, senyawa merkuri anorganik (terutama merkuri kloride), dan senyawa merkuri organik (terutama methil merkuri).

\section{Kandungan Logam Berat Hg Air}

Pengukuran logam berat Merkuri $(\mathrm{Hg})$ di perairan diambil menurut satasiun pengambilan sampel markuri dalam daging ikan, seperti pada 2

Tabel 2. Kadar Logam Berat Merkuri (Hg) Di Dalam Air Di Wilayah KJA Ikan Patin (Pangasius Hyphopthalmus) Danau Sipin Jambi.

\begin{tabular}{llrrrrr}
\hline No & Stasiun & \multicolumn{2}{c}{ Waktu Pengambilan Data } & \multicolumn{2}{c}{ Rataan } & Kedalaman \\
\cline { 3 - 7 } & & Minggu 1 & Minggu2 & Minggu 3 & $(\mathrm{ppm})$ & $(\mathrm{m})$ \\
\hline \multirow{2}{*}{1} & I. Lentik & & & & & \\
2 & St11 & 0,0001 & 0,0001 & 0,0009 & 0,00037 & 4,0 \\
& St12 & 0,0001 & 0,0001 & 0,0007 & 0,00030 & 5,0 \\
& Jumlah & 0,0002 & 0,0002 & 0,0016 & 0,00067 & 9,0 \\
& Rataan & 0,0001 & 0,0001 & 0,0008 & 0,00033 & 4,5 \\
& 2.Lotik & & & & & \\
3 & St23 & 0,0001 & 0,0001 & 0,0004 & 0,00020 & 3,5 \\
4 & St24 & 0,0001 & 0,0001 & 0,0005 & 0,00023 & 3,7 \\
& Jumlah & 0,0002 & 0,0002 & 0,0009 & 0,00043 & 7,1 \\
\hline & Rataan & 0,0001 & 0,0001 & 0,00045 & 0,00022 & 3,6 \\
\hline
\end{tabular}

Kandungan akumulasi logam berat di perairan Danau Sipin diambil pada empat posisi titik, menunjukan bahwa kadar $\mathrm{Hg}$ air berada 0,0001 - 0,0009 ppm dan nilai ratarata 0,0001 - 0,0008 ppm. Nilai kandungani $\mathrm{Hg}$ ini merupakan lebih rendah bila dibandingkan baku mutu yang dikeluarkan oleh Kementerian Negara Lingkungan Hidup No. 51 tahun 2004 nilai ambang batas untuk logam berat $\mathrm{Hg}$ di perairan, khususnya untuk biota adalah 0,001 mg/l, maka kandungan logam berat $\mathrm{Hg}$ di Perairan Danau Sipin masih berada pada ambang batas normal. 
Masuk bahan toksit markuri kedalam badan perairan Danau Sipin berasal dari aliran air Sungai Batnghari dan MCK dari rumah sakit, hotel dan rumah tangga di wilayah Danau Sipin. Menurut Effendi (2003) bahwa pencemaran memasuki badan air dengan berbagai cara, misalnya melalui atmosfer, tanah, limpasan (run off) pertanian, limbah domestik dan perkotaan, pembuangan limbah industri, dan lain-lain .

Dilihat $\mathrm{Hg}$ air pada tabel 2 nilai yang kecil didalam perairan Danau Sipin diperkirakan disebabkan banyaknya ditemukan tubuhan air seperti eceng gondok (Eichhornia crassipes) dan ikan sapu-sapu (Hypostomus plecostomus) yang ikut mengabsorbsi $\mathrm{Hg}$ air didalam perairan, sehingga tingkat pencemaran $\mathrm{Hg}$ di air menjadi rendah. Bahan logam yang diserap oleh makhluk hidup akan mengganggu kehidupan biota tersebut. Menurut Carvan et al. (2005) bahwa logam berat memiliki berbagai macam efek pada pertumbuhan, reproduksi, dan kelangsugan hidup biota akuatik. Pengaruh antara logam berbentuk ionik, dan organik, serta dalam lingkungan akuatik yang dipengaruhi oleh $\mathrm{pH}$, temperatur, dan kehadiran ion lain. Menurut Herawati, (1980) merkuri dapat menggumpalkan lendir pada permukaan insang dan merusak jaringan insang sehingga ikan mati. Huckabee dan Griffith dalam EIFAC (1980) jelaskan bahwa kadar 0,001 ppm merkuri $\left(\mathrm{HgCl}_{2}\right)$ dan selenium $\left(\mathrm{Se}_{2}\right)$ dapat mereduksi dalam kantong telur ikan mas (Cyprinus carpio).

\section{Faktor Konsentrasi}

Faktor konsentrasi (FK) merupakan rasio kadar logam dalam tubuh ikan dengan kadar logam dalam air. Faktor konsentrasi daging untuk logam $\mathrm{Hg}$ pada masing-masing stasiun berturut-turut sebesar adalah 2,80; 3,37; 0,96; 2,20 ppm. Faktor konsentrasi logam yang besar mengindikasikan ketersediaan logam yang lebih besar di lingkungan (Wiener dan Giesy 1979). Faktor konsentrasi ini dapat dilihat pada Gambar 4.

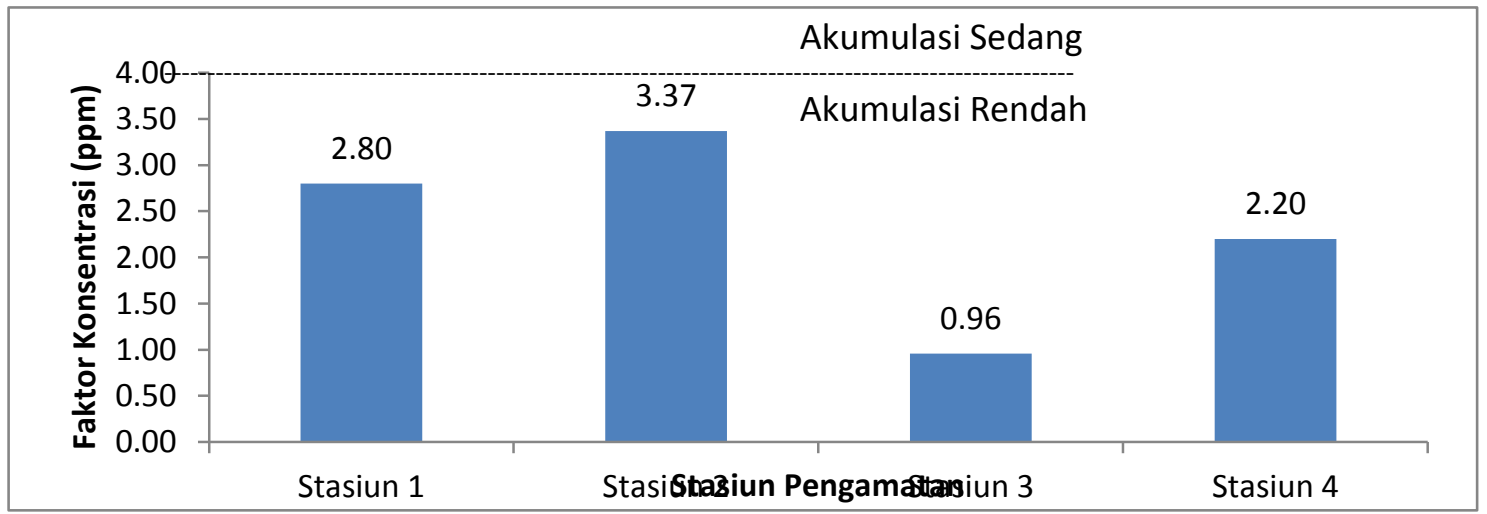

Gambar 4. Faktor Konsentrasi Akumulasi Logam Dalam Daging Terhadap Konsentrasi Logam Dalam Air Di Perairan Danau Sipin Jambi

Hasil konsentrasi logam berat tersebut merupakan hasil komposit dari sebagian contoh yang didapatkan di perairan Danau Sipin. Hasil ini diharapkan dapat mewakili perairan secara keseluruhan. Faktor konsentrasi gambar 4 menunjukan Indek Faktor Kosentrasi (FK) rendah, karena FK dibawah angka standar kisaran 100. Akumulasi logam pada ikan bergantung pada lokasi, kebiasaan makan, tropik level, umur, ukuran, lama terpapar logam, dan aktivitas regulasi homeostatis pada ikan (Sankar et al. dalam Ashraf et al. 2012). 
Perbedan Indek Kosentrasi antar perlakuan, kemungkinan disebabkan oleh jumlah logam $\mathrm{Hg}$ pada lokasi KJA tersebut, selain ini dapat disebabkan pula oleh kemampuan akumulasi logam yang berbeda-beda oleh setiap makhluk hidup. Selain itu, perbedaan konsentrasi setiap jenis logam di setiap organ juga dapat disebabkan bentuk kimiawi yang berbeda-beda dari setiap logam yang akan diserap dan diekskresikan dengan perbedaan kecepatan yang besar (Phillips dalam Connell dan Miller 1995). Retensi pencemar oleh makhluk hidup yang berbeda lebih bergantung pada perbedaan laju metabolisme dan pengeluaran (Moriarty dalam Connell dan Miller 1995).

\section{Parameter Kualitas Air}

Tabel 3. Data Parameter Kualitas Air Saat Pengamatan Kandungan Logam Berat Merkuri (Hg) di KJA Ikan Patin Danau Sipin Jambi (ppm)

\begin{tabular}{|c|c|c|c|c|c|c|c|c|c|c|c|}
\hline \multirow[t]{3}{*}{ No } & \multirow[t]{2}{*}{ Stasiun } & \multicolumn{9}{|c|}{ Waktu Pengambilan Data } & \multirow{3}{*}{$\begin{array}{c}\text { Kedalaman } \\
(\mathrm{m})\end{array}$} \\
\hline & & \multicolumn{3}{|c|}{ Minggu 1} & \multicolumn{3}{|c|}{ Minggu 2} & \multicolumn{3}{|c|}{ Minggu 3} & \\
\hline & $\begin{array}{l}\text { I. } \\
\text { Lentik }\end{array}$ & Suhu & $\mathrm{pH}$ & $\mathrm{DO}$ & Suhu & $\mathrm{pH}$ & $\mathrm{DO}$ & Suhu & $\mathrm{pH}$ & $\mathrm{DO}$ & \\
\hline 1 & St11 & 31 & 7,2 & 8,8 & 30 & 6,6 & 6,6 & 32 & 6,2 & 6,8 & 4,0 \\
\hline \multirow[t]{4}{*}{2} & St12 & 32 & 7,1 & 5,6 & 31 & 6,5 & 8,3 & 32 & 7,6 & 8,0 & 5,0 \\
\hline & Jumlah & 63 & 14,3 & 14,4 & 61 & 13,1 & 14,9 & 64 & 13,8 & 14,8 & 9,0 \\
\hline & Rataan & 31,5 & 7,2 & 7,2 & 30,5 & 6,6 & 7,5 & 32 & 6,9 & 7,4 & 4,5 \\
\hline & 2. Lotik & & & & & & & & & & \\
\hline 3 & $\mathrm{St} 23$ & 31 & 7,1 & 8,8 & 30 & 7,2 & 7,5 & 33 & 7,2 & 7,3 & 3,5 \\
\hline \multirow[t]{3}{*}{4} & $\mathrm{St} 24$ & 31 & 7,1 & 9,8 & 30 & 6,5 & 6,5 & 30 & 7,5 & 9,5 & 3,7 \\
\hline & Jumlah & 62,0 & 14,2 & 18,6 & 60 & 13,7 & 14 & 63 & 14,7 & 16,8 & 7,1 \\
\hline & Rataan & 31,0 & 7,1 & 9,3 & 30 & 6,9 & 7,0 & 31,5 & 7,4 & 8,4 & 3,6 \\
\hline
\end{tabular}

Parameter kualitas air selama penelitian tabel 3 untuk setiap stasiun pengamatan menunjukkan kisaran kualitas air yang optimal baik pada ekologi lentik maupun lotik. Faktor ekologi perairan lentik kisaran suhu rataan $30,5-32{ }^{\circ} \mathrm{C}, \mathrm{pH} 6,6-7,2$, dan DO 7,2 -7,5 ppm dan stasiun lotik kisaran suhu rataan $30-31,5^{\circ} \mathrm{C}, \mathrm{pH} 6,9-7,4$ dan DO 7,0 - 8,4 ppm. Kisaran parameter ini layak untuk budidaya ikan patin (Pangasius hyphopthalmus), karena dapat mendukung pertumbuhan dan kelangsungan hidupnya. Menurut Ghufran (dalam Menggawati dan Saptono 2012) dimana air yang digunakan untuk pemeliharaan ikan patin harus memenuhi kebutuhan optimal ikan. Kualitasnya harus baik, yaitu : suhu air berkisar antara $25-33^{\circ} \mathrm{C}$., pH air 6,5-9,0 optimal $7-8,5$. dan oksigen terlarut (DO) antara 3 - 7 ppm, optimal $5-6$ ppm.

Suhu sangat mempengaruhi pertumbuhan ikan terutama di daerah tropik karena mempengaruhi nafsu makan ikan dan laju pertumbuhan ikan. Bila suhu terlalu rendah maka pertumbuhan ikan akan lambat karena proses metabolisme menjadi lambat dan nafsu makan ikan akan menurun. Menurut Gusrina (2007), kisaran suhu air yang sangat diperlukan agar ertumumbuhan ikan-ikan pada perairan tropis dapat berlangsung berkisar antara $25^{\circ}-32^{\circ} \mathrm{C}$. Suhu air sangat berpengaruh terhadap proses kimia, fisika dan biologi di dalam perairan. Perubahan suhu pada suatu perairan akan mengakibatkan berubahnya semua proses di dalam perairan. Hasil pengukuran suhu rata-rata berkisar antara $30-32{ }^{\circ} \mathrm{C}$. Kordi dan Tancung (2010), menjelaskan bahwa kisaran suhu yang optimal bagi kehidupan ikan patin adalah $25 \mathrm{oC}-32 \mathrm{oC}$ 
Kisaran derajat keasaman $(\mathrm{pH})$ selama tiga kali pengamatan pada empat titik pengamatan $\mathrm{pH}$ rata adalah $\mathrm{pH} 6,9-7,4 \mathrm{pH}$ ini berada dalam batas optimum untuk pertumbuhan dan kelangsungan hidup ikan. Menurut Rusdy (2009) $\mathrm{pH}$ yang baik untuk budidaya ikan adalah 5.5 - 9.0. Gusrina (2007) menjelaskan bahwa titik kritis antara asam dan basa untuk kematian ikan adalah masing-masing pH 4 dan pH 11.

Kandungan oksigen terlarut (DO) dalam air berpengaruh terhadap proses metabolisme dalam tubuh ikan. Jika kandungan oksigen turun dibawah batas tertentu, maka laju metabolisme berjalan lambat dan aktivitas menurun (NRC, 1977). Menurut Rusdy (2009) kualitas air yang diperlukan berbeda untuk setiap jenis ikan. Untuk memperoleh produksi ikan secara optimal, kadar oksigen yang dibutuhkan adalah di atas 5 ppm. Apabila kadar oksigen kurang dari 5 ppm, nafsu makan ikan akan berkurang dan pertumbuhannya terhenti. Dari hasil pengamatan nilai DO terlarut adalah 7,0 - 8,4 ppm berarti nilai DO ini relatif sangat baik untuk kehidupan ikan terutama ikan patin. Menurut Cahyono ( 2001) kebutuhan oksigen yang sesuai untuk kehidupan ikan patin adalah 4,56-6,9 ppm.

\section{KESIMPULAN}

Akumulasi kandungan logam berat merkuri ( $\mathrm{Hg}$ ) ikan patin (Pangasius hyphopthalmus) yang dipelihara di perairan Danau Sipin Jambi pada air kisaran nilai rata-rata 0,0001 - 0,0008 ppm dan dalam daging 0,1660 - 0,2772 ppm. Indek Faktor Konsentrasi Hg pada ikan uji 0,96 - 3,37. Sehingga dapat dikatakan perairan Danau Sipin Jambi belum tercemar oleh logam berat $\mathrm{Hg}$ dan ikan patin budidaya sebagai bahan pangan masih aman untuk dikosumsi manusia.

\section{DAFTAR PUSTAKA}

Apriadi, D. 2005. Kandungan Logam Berat $\mathrm{Hg}, \mathrm{Pb}$ dan $\mathrm{Cr}$ pada Air, Sedimen dan Kerang Hijau (Pema viridis L.) di Perairan Kamal Muara, Teluk Jakarta. IPB, Bogor. Skripsi.

Ashraf M, Maah MJ, Yusoff I. 2012. Bioaccumulation of heavy metals in fish species collected from former Tin Mining catchment. Int J Environ Res. 6(1):209-218.

BSN (Badan Standar Nasional). 2006. SNI 01-2729.2-2006 tentang Ikan Segar Bagian 2:Persyaratan MutuBahan Baku. BSN. Jakarta.www .ri.go.id/produk _ uu/isi/ pp $2001 / \mathrm{pp} 82$ '01.htm

Cahyono, B. 2001. Budi Daya Ikan Di Perairan Umum Penerbit Kanisius IKAPI. 44 halaman

Carvalho, C.S, MN Fernandes. 2006. Effect of temperature on copper toxicity and haematological responses in the Neotropical fish, Prochilodus scrofa at low and high pH. Aquaculture. 251:109-117.

Carvan MJ., Heiden TK., Tomasiewicz H. 2005. The utility of zebrafish as a model for toxicological research. Biochemistry and Molecular Biology of Fishes vol 6. Editor T. P. Mommsen and T. W. Moon. Elsevier.

Connell, D.W. dan G.J. Miller. 1995. Kimia dan ekotoksikologi pencemaran. Penerbit Universitas Indonesia, Jakarta.

Darmono. 2001. Lingkungan Hidup dan Pencemaran. Universitas Indonesia, Jakarta.

Effendi, H. 2003. Telaah kualitas air : Bagi pengelolaan sumberdaya dan lingkungan perairan. Penerbit kanisius. Yogyakarta.

EIFAC, 1980. Water quality Criteria For European Freshwater Fish. FAO Of The United Nations, Rome. 49 p. 
Gusrina, 2007 Budidaya Ikan. Jilid 1. Direktorat Pembinaan Sekolah Menengah Kejuruan Direktorat Jenderal Manajemen Pendidikan Dasar dan Menengah Departemen Pendidikan Nasional. 160 halaman

Herawati. T. 1980. Pengaruh Pencemaran Air Terhadap Ikan. Di dalam Majalah Pertanian, No.28/I, Jakarta. Halaman 39-45.

KKP (Kementrian Kelautan dan Perikanan). 2014. Statistik perikanan budidaya kolam [Internet]. [diunduh 10 Februari 2015]. Tersedia pada http://sidatik.kkp.go.id.

Kordi, K.M.G.H., Tancung A.B. 2010. Pengelolaan Kualitas Air Dalam Budidaya Perairan. Rineka Cipta, Jakarta

Lasut, MT. 2009. Proses Bioakumulasi dan Biotransfer Merkuri (Hg) pada Organisme Perairan di dalam Wadah Terkontrol. Jurnal Matematika Dan Sains,September 2009, Vol.14 No.3

Kompas.Com(2008). Bahaya Logam Berat dalam Makanan. http://edukasi. kompas. com/read/2008/09/21/11254074/Bahaya.Logam.Berat.dalam.Makanan

Makarim, N. 2003. Keputusan Menteri Negara Lingkungan Hidup Nomor : 115 Tahun 2003 Tentang Pedoman Penentuan Status Mutu Air Menteri Negara Lingkungan Hidup, Jakarta

Menggawati, I dan Saptono 2012. Parameter Kualitas Air untuk Budidaya Ikan Patin (Pangasius pangasius) di Karamba Sungai Kahayan, Kota Palangka Raya. Jurnal Ilmu Hewani Tropika Vol.1 No. 1 Juni 2012. ISSN 2301-7783

National Risearch Counsil (NRC). 1977. Nutrient Reqruitment of Warmwater Fishes. National Academy of Sciences, Washington DC. 78p

Raja, P. S. Veerasingam., G. Suresh., G. Marichamy., R. Venkatachalapathy. 2009. Heavy metals concentration in four commercially valuable marine edible fish species from Parangipettai coast, South East Coast of India. Int $J$ of Animal and Veterinary Adv. 1(1):10-14.

Riani, E. 2012. Perubahan Iklim dan Kehidupan Biota Akuatik (Dampak pada Bioakumulasi Bahan Berbahaya dan Beracun \& Reproduksi). Bogor (ID): IPB Press.

Rusdy 2009. Air Untuk Budidaya Perikanan. http:// id.shvoong.com/exact-sciences/ agronomy-agriculture/1933033

Setiawan, A.A, Eddy, S. 2011. Kandungan Pb pada Berbagai Jenis Ikan di Perairan Sungai Musi Palembang Jurnal Mandiri Agritek, kopertis Wilayah II.

SNI, 2009. Batas maksimum cemaran logam berat dalam pangan. SNI, 27387 : 2009. http://sertifikasibbia.com/upload/logam_berat.pdf

Soekarnoputri, M. 2001. Peraturan Pemerintah Republik Indonesia Nomor 82 Tahun 2001. Tentang Pengelolaan Kualitas Air Dan Pengendalian Pencemaran Air. Presiden Republik Indonesia, Jakarta

Wiener JG., J.P J.r. Giesy. 1979. Concentration of $\mathrm{Cd}, \mathrm{Cu}, \mathrm{Mn}, \mathrm{Pb}, \mathrm{Zn}$ in fishes in a highly organic softwater pond. J Fish Res Bd Can. 36:270-279. 